\title{
Problems and strategies that exist in Sino-Japanese trade
}

\author{
Ningning LI \\ Weifang University of Science \& Technology \\ Shouguang 262700 China
}

\begin{abstract}
China and Japan have been important countries in East Asia. Whether the development of trade relations between the two countries is good, has a major impact on the economy of East Asia as well as accelerates regional trade liberalization and financial cooperation in East Asia. It also conducts to East Asia peace and stability. The two countries are important trade partners of each other, mutually first and third largest trading partner, which makes a natural advantage of economic cooperation. Since the establishment of diplomatic relations between China and Japan, they have achieved remarkable economic and trade relations, trade and capital flows prosperity, together with having new progress in SinoJapanese cooperation in science and technology, environmental protection and financial exchanges, etc.. While the two economies promote each other, it also leads to their close exchange of country's political culture. Closer contacts accompanied with increased friction, in this context, our focuses should be what the main problems existing in SinoJapanese trade relations are, how to defuse bilateral trade unfavorable factors and how to create a new situation of SinoJapanese trade cooperation, etc. In this paper, through the Sino-Japanese trade relations phased interpretation, we will analysis the current situation of Sino-Japanese economic and trade cooperation, explore major issues existing between the two countries, and try to advise on the development of economic and trade relations for Sino-Japanese.
\end{abstract}

Keywords- Sino-Japanese trade relations; existing problems; suggestions

\section{INTRODUCTION}

\section{A. Negative growth in trade volume}

September 11, 2012, the Japanese government and the so-called "owner" of Diaoyu Islands signing the formal "island purchase contract", has taken a substantial step for the implementation of the nationalization of the Diaoyu Islands. Japan's violation of China's sovereignty practices seriously affected the middle Sino-Japanese relations in all aspects. For Japan, China is Japan's largest trading partner, and the trade with China has an important impact on the economic development of Japan. The data shows that in 2011 the Sino-Japanese trade volume reached 344.9 billion US dollars, while Japanese exports to China to \$161.4 billion, making up $20.6 \%$ of Japan's total exports, an increase of 8.3 comparing to past year. And this data is only 8 percent a decade ago, if Japan from China's imports amounted to \$ 183.4 billion, an increase of $20 \%$ on year-on-year growth. If Japan trade relations fluctuate even worse, Japan's economic burden will increase which makes growth of its domestic economy slow. The Diaoyu Island incident that caused by Japan intensified this process, not only worsen the situation due to the Sino-Japanese dispute over the Diaoyu Islands relations, but also affect the economic and trade relations between China and Japan, and even some Japanese economic exchange project has been delayed, besides communication between enterprises also appears to be a barrier. Affected by this incident, the loss of the Japanese auto industry cannot be ignored, the Japanese production of cars in China's automobile market having faced many of the competition. The Japanese carmakers once suspend the business due to the impact of the crisis of the Diaoyu Islands, such as Honda, Toyota, Nissan and other operations. But this time, according to conservative estimates, these companies caused a loss of nearly $\$ 250$ million. Though China is the world's largest car market, and the car takes a lot, 2012 In September the Japanese car sales in the Chinese market has been hit with a devastating, according to Japanese media reported on September 25, 2012, that the Toyota Lexus would cut 20 percent production, Toyota's sales fell 30 percent.

\section{B. Confidence of trade business fell}

If the Diaoyu Islands incident escalates, regional financial cooperation will lead to the occurrence of stagnation, and will adversely affect the financial stability. Because of the Diaoyu Islands crisis, the future development of Sino-Japanese economy is facing many variables, these variables including investments in Japanese companies slowdown, and some Japanese companies in China is adjusting its output plan. After the 3.11 earthquake in Japan, the overall economic development appears the slow emergence and direct exports shows weak trend, meanwhile, because of the adverse effects of the nuclear accident, Japan must import large quantities of oil, natural gas and other energy sources, which results in a trade deficit in foreign trade exchanges, and then the outbreak of the Diaoyu Islands dispute event causes a serious setback in the Japanese economic and trade cooperation, most costly losses mainly in the automotive industry and tourism. From the macro perspective, this effect mainly caused a heavy blow in exports to Japan. Since the summer of 2011, quantitative easing monetary policy for public investment and expanding policy to stimulate the economy could effectively promote economic recovery, but the goal to promote economic reconstruction in post-earthquake recovery is hampered by different degrees due to the European debt crisis, the impact of the world economic slowdown background, plus the impact of the event the Diaoyu Islands in Japan. 
The amount of Japanese investment in Mainland China is large, becoming one of China's major sources of foreign investment, but along with rising labor costs in China, Japanese-funded enterprises in China's profit decline, once substantial investment growth in China continues. Not only like this, some Japan enterprises that in China have also strengthened the related equipment and technology upgrading, and these initiatives will undoubtedly promote the optimization and upgrading of industrial structure of China. But the outbreak of the Diaoyu Island incident attacks the investment confidence of Japanese corporate in a way, as well as adversely affects the economic development of both countries.

Some Japanese companies believe that the risk of investing in China will increase, the reasons why they think so is that, on the one hand is because of the outbreak of the Chinese boycott activities in Japan, on the other hand is mainly a marked slowdown in China's economic growth, risks of China's Investment will continue to increase, in spite of the inevitable risk during investing.

\section{Enterprise Trade readjustment}

As china's economic growth beginning to slow down, even though the overall overseas mergers and acquisitions of Japanese companies remain the highest growing rate, it will inevitably have some impacts in Japan. In order to find a way for their own economic development, Japan is actively adjusting their investment activities and plans.

Diaoyu Island incident triggers the tension in SinoJapanese economic relations, and the impact on China's trade cannot be ignored. In the field of advanced manufacturing, Japan plays a major supplier role of intermediate products and production equipment. The Japanese electronics materials, semi-conductor wafers occupy a large market share in a global trade, and Japan exports many high-end high-tech products to China. If a trade war breaks out between China and Japan, China blocking exports to Japan, plus the EU and the US export market is a downturn, China's strategy to achieve a stable export target will be very difficult task. China and Japan are highly complementary in economic development, especially in automotive industry, electronic products industry and others. China is in the position of downstream production line, while Japan is in the upper position of the production line. The products that Japan exports to China mostly are mechanical and electrical products, chemicals and transport equipment, etc. These products are in the upstream industry chain, providing critical parts and electronic components for China's related electronics industry. If Japan once restricts the supply of these products, these core components China will be in short supply, which will have a significant negative impact on the Chinese market.

\section{Enterprise Trading costs rising}

Diaoyu Island incident is a political conflict, and it has an extremely important role for the healthy development of Sino-Japanese economy.

. Because of the impact of the Diaoyu Islands crisis, the number of Chinese tourists traveling to Japan is greatly reduced. As the Japanese government continues to stir up the Diaoyu Islands event, the phenomenon that Chinese tourists who travel to Japan unsubscribe and reduce frequently occur, and the total number of travel agents is over $40 \%$. This phenomenon makes a big impact on its economic growth, as Japan a destination for Chinese tourists traveling abroad. Although, according to "Economic Information Daily" reported that the Japanese government proposed a "tourism nation", which is a tourism development policy to treat Chinese nation as an important source of tourists. Japanese Land and Transport Minister said that tourism exchange is very important, and the impact of tourism what the Diaoyu Islands incident caused between the two countries should be avoided, but the situation is still not optimistic. Affected by the downturn of tourism, the aviation industry suffers the brunt of the Diaoyu Islands incident. ANA data showed Chinese and Japanese planes team tickets have been cancelled, and the aviation industry apparent stagnation, as well as the business travel has gradually affected. In a short period of time, the team plane ticket cancelling increases. According to the Japanese airline's data show that, during September 2012 to November, the number of seats cancelled raise up to 950.The number of seats departure from Japan to China is 4600, and the number of seats from China to Japan is 5250. While the Japanese market is facing collapse, tourist hotspots formed a strong tourism market competition such as South Korea, United States, Canada, Australia and New Zealand.

\section{DISCUSSION ABOUT TRADE MEASURES TO IMPROVE SINO-JAPANESE}

\section{A. Safeguard their self-interests earnestly}

Using WTO rules protect the legitimate rights and interests of China's foreign trade. As a WTO member, we should actively use WTO trade rules to quickly resolve trade friction between China and Japan, or submitted trade disputes between China and Japan to the WTO's Dispute Settlement Body, and let the problem get a fair and timely solution, which makes the larger International pressure on Japan to form a deterrent.

Establish an effective system of early warning mechanisms and bilateral trade deal with trade protectionism. For the Japanese trade protectionism and trade barriers on the Japanese side of the product set, China should establish and improve related remedies, in case that after friction we can quickly respond to protect the vital interests of Chinese enterprises, reduce the losses to a minimum.

Implement diversify trade products exports to Japan. At present, China's export market has a strong dependence on Japan. Once the economic crisis arisen or trade disputes with Japan will affect the overall exports. It's vital to improve the resilience of China's foreign trade, reduce the concentration of export markets, reduce the over-reliance on product structure or industry structure adjustment of the part of international market, make the product diversification and market diversification. 


\section{B. Play the role of industry associations}

In the Sino-Japanese trade disputes, industry associations should play an important role in foreign trade disputes, though the state also plays an active role. Their own power is very limited in resolving Sino-Japanese trade dispute. The national government's power is conducted to grasp the whole, for some highly specialized industry, and it also needs to participate in industry associations. Industry associations possess its own expertise on international business is familiar with trading rules and regulations, and can respondent which is required to provide information in a timely manner and to coordinate the relationship between domestic enterprises, avoiding companies having some of the drawbacks of the respondent. States may also authorize the leadership of enterprises to industry associations, anti-dumping and protect the exercise of the functions of their business.

\section{Maintain the growth of bilateral trade}

Bilateral trade between China and Japan is mutually beneficial, and the development of bilateral trade in mind is in order to promote the economic development of the country. Thus maintaining the growth of Sino-Japanese bilateral trade, achieving the economic win-win has an important role in guiding on resolving trade disputes between China and Japan. Maintained the bilateral trade between China and Japan at the current trend of economic globalization and regional integration is the most effective way to establish a free trade area in Japan and strengthen regional cooperation with other Asian countries in the Japanese economy. Actively seeking FTA development, strengthening political and economic relations between the two countries, expanding bilateral cooperation in the field is necessary to improve the international competitiveness of China and Japan and have important effect to earn greater mutual economic interests, which makes cooperation in the competition and promote common development through cooperation.

\section{Try to avoid trade friction}

The transformation of foreign trade growth mode changing the past, extensive mode of growth in trade with Japan should not only focus on quantity and speed, but also focus on the quality and efficiency of trade. Increasing the science and technology levels of the enterprise, adjusting the industrial structure and other methods can construct a sustainable, cost-effective, competitive foreign trade growth way, which creates our active position in international trade friction.

Adhere to the policy of expanding domestic demand, and fully exploit the potential of the domestic market. In the market economy, both domestic and foreign trade enterprises need to realize the value of the product and the final stage of profit maximization, so that domestic and foreign trade can replace each other. This has a more special meaning for imbalance situation between the countries in terms of regional development.

\section{E. Achieve the transformation of dominant industries}

In China's industrial structure of foreign trade, the first industry output still account for a large proportion, and the total import and export situation of the second, third industry has a greater impact on the value of imports. In addition, China's exports to major markets are the smaller benefits field of clothing, toys, and manufacturing, on the contrary, the Japanese high-tech products occupy a large part of the market share in the country. In order to change this situation, it is necessary to achieve the transformation of China's competitive industries, develop high-tech industries, create big brands, make innovations to optimize the industrial structure, develop secondary and tertiary industries to improve the overall competitiveness of China's foreign trade. And then it plays the advantages of China's trade with Japan.

\section{CONCLUSIONS}

Sino-Japanese trade and economic development is meeting a new historical opportunity: with the continuous development of national economies in East Asian countries, East Asia needs to further deepen communication in regional economic cooperation. China and Japan in East Asia is the political, economic power, so the needs to further strengthen cooperation are inevitable. The Japanese economy had survived from the downturn and is recovering, which provide the Sino-Japanese economic and trade cooperation better conditions for further. China's development goals, principles of foreign trade and economic cooperation will accelerate consociation space for China and Japan. Although there are differences in the fields of energy, environmental protection, etc., the economy remaining win-win cooperation is the common aspiration of the two countries.

\section{References}

[1] Melody Wang (Melody) research. Under the Diaoyu Islands crisis in Japan Trade Development [D]. Shandong University, 2014.

[2] Yu Wenying. Comparison of the Sino-Japanese trade structure and trade relations in a number of problems [D]. Yanbian University, 2002.

[3] Li Jing. Sino-Japanese economic and trade relations Li Jing, problems and suggestions [D]. Yanbian University, 2013.

[4] Wang Yu. After China's reform and opening up Yanbian Korean study exchange partnership Korea [D]. Yanbian University, 2012.

[5] Bai Guanbo. Impact on China's economic development and trade cooperation between China and South Korea [D]. Fudan University, 2008 . 